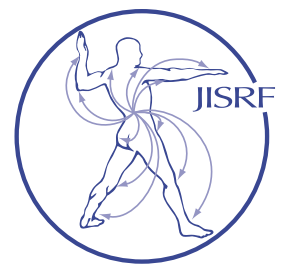

\title{
Life Lost Too Soon: Navy Corpsman from Ohio Killed in Afghanistan Attack August 26, 2021
}

McTighe, $T^{1}$

$\mathrm{N}$ avy Corpsman Maxton "Max" W. Soviak, HM3 (22 years old) of Berlin Heights, Ohio, was one of the 13 U.S. service members killed while supporting non-combatant evacuation operation in Kabul, Afghanistan.

Max was advanced to the rank of Hospital Corpsman Third Class "as a result of his brave actions in support of fellow service members," according to a Navy statement. He was also posthumously awarded the Purple Heart and Fleet Marine Force Corpsman warfare badge.

He enlisted in September 2017 and attended Hospital Corpsman School in San Antonio, Texas, before postings in Guam and at Camp Pendleton.

Soviak lived in Berlin Heights and graduated from Edison High School in 2017, where he also wrestled and played football.

The Soviak family said Maxton was proud of being part of a state champion wrestling team and a final four state playoff football team two years in a row, "but he was most proud to be a Navy Corpsman and a 'devil doc' for the Marines."

I wanted to take this opportunity to pass on my condolences to the Soviak Family, and friends. Seeing and read- ing about Max made me think how blessed I have been since Max and I started out with very similar paths to adulthood.

Like Max, I joined the U.S. Navy out of High School (Euclid High). We were both from Northern Ohio. Max being from Berlin Heights and I was from Euclid, Ohio. He joined during the Afghan war in 2017 and I joined during the Vietnam Conflict in 1969. Max went on to attend the Hospital Corpsman School in San Antonio, Texas. I did my Hospital Corps School at Great Lakes, Illinois. Max went on to posting in Guam and at Camp Pendleton before serving in Afghanistan. I went on to posting at Key West Naval Hospital prior to my training at Marine Corps Base Camp Lejeune, NC, and Camp Lejeune Naval Hospital (HM-0000) and Field Medicine Service School (HM- 8404) Camp Lejeune NC. The Field Medical Service Technician (FMST) course is designed
Navy Corpsman Maxton "Max" W. Soviak January 22, 1999 - August 26, 2021 for E1 to E6 Hospital Corpsmen. Training has a mix of classroom and field training. Emphasis is placed on learning field medicine by using the principles of Tactical Combat Casualty Care (TCCC).

Max served in the final days of a long drawn out war, 
and too often we see our loved ones die at the final stages of a terrible conflict. I was luckier than Max - I did not have to serve in a combat situation. I missed out of serving in Vietnam since my brother was also enlisted (Army) and serving in Vietnam. He was blessed with being able to come home after his tour of duty.

Max served for four years and was advanced to the rank of Hospital Corpsman Third Class. I was discharged after my four years (1973) as a Third Class Petty Officer.

Max did not have the opportunity to see where his Navy training would have take him. I, on the other hand, benefitted because my Navy experience prepared me for a 50 year career in Orthopaedic medicine.

There is little doubt in my mind that Max would have gone on to make many contributions in the medical field. Naval training in the health care field is the best in the world and Max lived and died making a difference. Max also made me think of my Father, Francis V. McTighe (Army/ Air Corps) who served in World War II as a Medic and was part of Operation Overlord, the battle began on June 6, 1944, also known as D-Day, when some 156,000 American, British and Canadian forces landed on five beaches along a 50-mile stretch of the heavily fortified coast of France's Normandy region. My Dad was also blessed to come home after his service.

Max, you make me proud. You will be remembered by many.
SUBMISSION HISTORY

Submitted: September 22, 2021

Accepted: September 22, 2021

Published: October 12, 2021

AUTHOR AFFILIATIONS

1 Timothy McTighe, Dr HS (hc); Joint Implant Surgery \& Research Foundation, 46 Chagrin Shopping Plaza, \#117, Chagrin Falls, OH 44022 US

(Direct reprint requests to Timothy McTighe, tmct@jisrf.org)

AUTHOR DISCLOSURES

The authors declare that there are no disclosures regarding the publication of this paper.

\section{COPYRIGHT \& OPEN ACCESS}

(C) 2019 McTighe. All rights reserved.

Authors retain copyright and grant the journal right of first publication with the work. Reconstructive Review is an open access publication and follows the Creative

Commons Attribution-NonCommercial CC BY-NC. This license allows anyone to download works, build upon the material, and share them with others for non-commercial purposes as long as they credit the senior author, Reconstructive Review, and the Joint Implant Surgery \& Research Foundation (JISRF). An example credit would be: "Courtesy of (senior author's name), Reconstructive Review, JISRF, Chagrin Falls, Ohio". 